\title{
Reclamation and Expulsion. Frontiers of City Expansion and the Loss of Public and Communal Spaces at Abidjan's Lagoonal Waterfronts
}

\author{
Irit Eguavoen $^{1}$ (D)
}

Accepted: 27 October 2021 / Published online: 19 January 2022

(C) The Author(s) 2022

\begin{abstract}
The paper analyses the motivations of actors who reclaimed and appropriated the banks of the Ebrié Lagoon in Abidjan, Côte d'Ivoire, which were in many cases marginal lands under public ownership. The analysis focuses on the evolution of two unplanned settlements, Soweto (from 1964) and Adjahui (from 2011). Practices of incremental place-making and residential stories connect these places, which are located opposite to one another at the Bay of Koumassi. The research questions are as follows: Why and by who were waterfronts reclaimed and appropriated? And how does reclamation entail social-economic inequalities and the loss of public and communal spaces? Conceptually, lagoonal waterfronts are approached as waterscapes, cultural landscapes with discursive representations. Their evolution is analysed by using the concepts of fixity and flows by Desfor and Laidley (2011). Findings show although tenure was highly insecure in the legal sense, use rights, house ownership and local power relations in Soweto were fixed for decades despite the fact that buildings, residents, local arrangements and the spatial form constantly changed. Though inhabitants increasingly entered the water space and the lagoon, the material condition of the settlement seemed stable because the process took place over many decades before urban renewal set dynamics in motion that speeded up the reclamation process and brought the waterscapes into flow.
\end{abstract}

Keywords Housing · Tenure · Land reclamation · Urban political ecology · Côte d’Ivoire · Africa

Irit Eguavoen

eguavoen@uni-bonn.de

1 Department of Geography, University of Bonn, Bonn, Germany 


\section{Introduction}

Back from our day of data collection on unplanned urbanisation in Abidjan in 2019, we embark the wooden ferry from Adjahui heading to Soweto whose shore can be seen across the lagoon. During the short transit, our research team crosses a number of boundaries: from land to water to land, from Port Bouët Municipality to Koumassi Municipality and from a fast-growing slum to an expanding middle-class neighbourhood. We pass through contested regimes of tenure: customary territories, public land and private properties, legitimated by tradition, defined by law or established by practice. The distance between the two shores visibly shrinks each year that we return. Soweto looks different each time too: a beach, a construction site, apartment blocks - a new quarter built on sand.

This study, which builds on ideas of Urban Political Ecology in the city (Cousins and Newell 2019), analyses the socio-political processes shaping waterfronts in the District of Abidjan, the economic capital of the Côte d'Ivoire. It focuses on various practices of incremental place-making and appropriating the reclaim. The research questions are as follow: Why and by who were waterfronts reclaimed and appropriated? And how does reclamation entail social-economic inequalities and the loss of public and communal spaces?

Abidjan, a coastal metropolis of 5 million inhabitants, comprises 10 municipalities (communes) and four prefectures (sous-préfectures) (INS 2015). Eight municipalities border the Ebrié Lagoon. Large areas of Abidjan are situated less than a metre above sea level, including much of Port Bouët Municipality and Grand Bassam, which straddle the lagoon and the Atlantic Ocean (Figure 1) ${ }^{1}$. Land tenure at Abidjan's watersides is contested. Residents of unplanned settlements, which were tolerated and neglected by the municipal councils and the district government for decades (politique de laissez-faire), have in recent times faced forceful evictions and gentrification.

Abidjan metropolis is an island city (Grydehøj 2015; see Figure 1), meaning that its original topography dominated by islands, peninsulas, the Ebrié Lagoon, wetlands and the Atlantic coastline resulted in historically grounded relations, as well as enduring dependencies between its urban form, society and aquatic environment. In its southern part, much of the land is in fact created by reclamation or siltation. The idea that these were wetlands and natural water spaces has faded from the collective memory of most Abidjanais. Few if any of Abidjan's lagoonal waterfronts remain natural spaces: they have been anthropogenically altered. Abidjan has served as a colonial capital (1933-1960) and a national capital (1960-1983). The city was originally founded by the French for colonial, geopolitical reasons. On a plateau at the lagoon front (today's Plateau Municipality), an envisaged port would be protected from the Atlantic Ocean and could easily be connected to the train line heading to the colony's hinterland. An interim wharf was constructed at the coast in Port Bouët connected to the plateau by a railway. Only in 1950 was the lagoon connected to the

\footnotetext{
1 Source: Apple maps (retrieved on 12.09.2021). Place names were inserted by the author.
} 


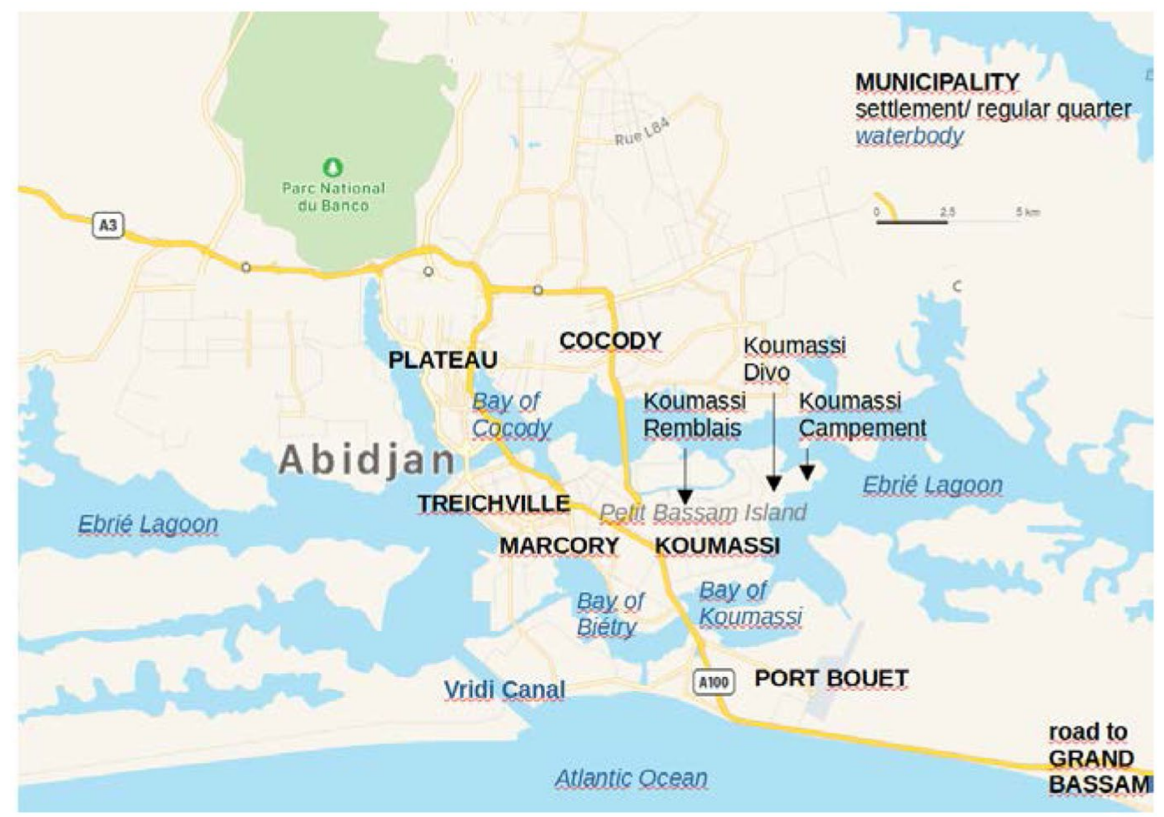

Figure 1 The District of Abidjan Source: apple maps (retrieved on 12.09.2021). Place names were inserted by the author

ocean via the construction of the Vridi Canal. Following the urban planning and segregation principles of French West Africa, the colonisers used the lagoon as a sanitation corridor to physically separate European from African populations. In this way, the Ebrié Lagoon was inscribed into the urban design of Abidjan from the very beginning.

The metropolis unsustainably exploits its central water body. While water pollution has accumulated over the past decades (Diarra 2015; UNEP 2015), future challenges already show on the horizon. Climate change projections suggest that parts of Port Bouët could be affected by sea level rise (Jallow et al. 1999), which in combination with coastal erosion could make these densely populated parts of Abidjan uninhabitable in the long run. Seasonal inundations, caused by multiple factors including sealing of the surface, blockage of drainage and sewage and the urbanisation of swamps and floodplains, are common. Mangrove belts used to serve as a natural buffer zone between land and water; however, the deforested urban banks of the lagoon are deprived of this protection and thus more vulnerable to waves. The management of the Ebrié Lagoon is regulated by national and international law and officially assigned to a number of government actors, including at least four national ministries and various agencies (Diarra 2015). 
In a study ranking global port cities according to the highest potential economic damages due to climate change-induced sea level rise and storms, Abidjan features as the only African metropolis among the top 20 (Hallegatte et al. 2013: 803), also because of the expected increase in construction of waterfront housing and infrastructure. About 13 years ago, Pottier et al. (2008) were merely concerned with water pollution, the loss of water space due to siltation and congestion of the lagoon though land reclamation in the northern and western parts of Petit Bassam Island occurred from the 1960s onwards. Since then, land reclamation from the Ebrié Lagoon has been extensive in the four southern municipalities, Treichville, Marcory, Koumassi and Port Bouët. Land reclamation is planned and supported by state authorities, for example, at the Bay of Cocody, at the industrial zones at the Bay of Biétry and at the international port in Treichville. Much of it, however, happens without their involvement or documentation.

Cartography in Abidjan has been under-financed for decades, and what little exists has depended on external funding. The period of the Ivorian civil war (2001-2010) and a violent post-electoral crisis (2010-2011) left a further gap in the documentation of spatial transformation. ${ }^{2}$ Of course, public authorities collect spatial data and create maps. Yet, their efforts are often fragmented, project-based and challenged by the lack of documentation in the past. The most recent city map available on the market (CESIG 2014) was produced by a private entrepreneur who had worked for the National Office of Technical Studies and Development (BNETD) until his retirement. Due to technical limitations alone, his map divides Abidjan into a southern water-dominated part on the front page and a terrestrial northern part on the back page. ${ }^{3}$ Many shorelines displayed on this map were outdated because of recent land reclamation. Planned land reclamation at the Bay of Cocody at the north of the lagoon took momentum in 2019. Planned reclamation at the Bay of Biétry in 2019/2020 supports the extension of the international port and industrial zones, as well as increases the communal space of Biétry Village, whereas at the Bay of Koumassi, reclamation is driven by residential sprawl and thus follows a pattern which has been essential for overall urban expansion in southern Abidjan (Figure 2) ${ }^{4}$. The extent of land reclamation at these two bays in 2021, which can be observed via Apple maps, suggests a dramatic reduction of water spaces.

Primary data for this paper was collected in 2016, 2018 and 2019 by a research team including the author, who was supported by one local assistant and two research assistants from Abidjan. Interview transcriptions, diary notes from

\footnotetext{
${ }^{2}$ During the civil war, the north of the country was controlled by rebel groups, while the south remained under the control of the government led by president Laurent Gbagbo. Catalyst to the violent outbreak was a referendum from 2000 that determined that both parents of a presidential candidate needed to be Ivorian citizens, which disqualified one of the candidates Alassane Ouattara from the elections. The overall conflict centred about belonging and migrants' citizen rights. Violent clashes after the election from 2010 arose between followers of Gbagbo and the winner of the elections Outtara. Since 2011, the liberal party Rassemblement des Républicains (RDR) under Ouattara governs the country.

3 Mr. Kena, director of CESIG (Cabinet d'Expertise en Systèmes d'Informations Géographiques), $03 / 2019$

4 Image from Apple maps (retrieved 18.02.2021) with place names inserted by the author. Brackets indicate evicted settlements.
} 


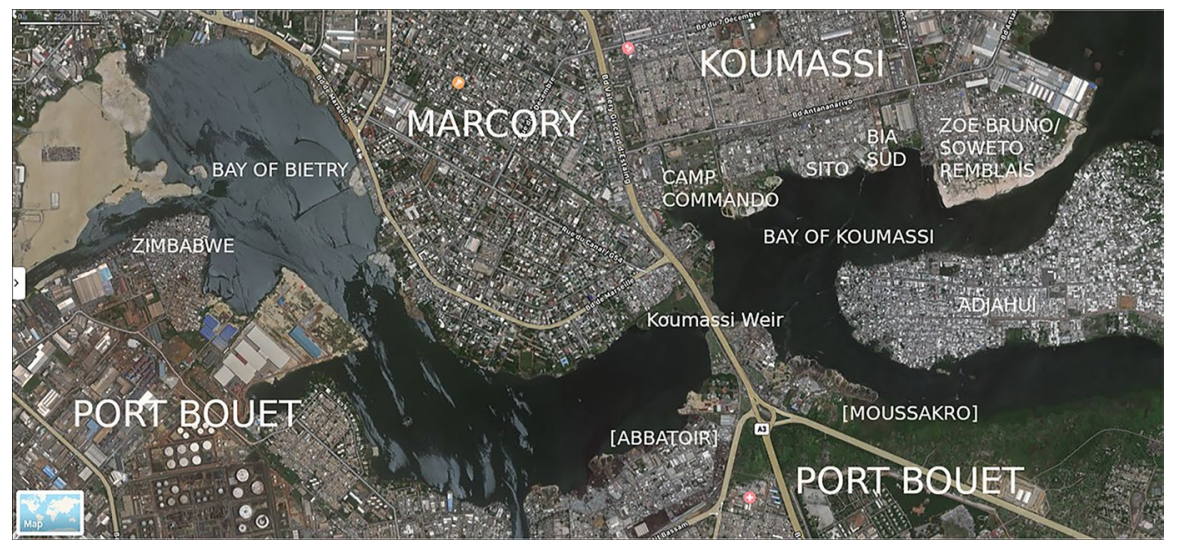

Figure 2 Land reclamation around southern bays of the Ebrié Lagoon. Source: apple maps (retrieved on 18.02.2021) with place names inserted by the author. Brackets indicate evicted settlements

observations and informal interviews provided primary data, as well as the author's photographs taken during transect walks along waterfronts and during boat trips. French interview transcriptions were translated to English by the author. For the contextualisation of the field data, a review of literature and media was utilised. A consultant employed by the project contributed remote sensing maps of waterfront development between 2008 and 2018 (see Acknowledgements). Findings from an ethnographic census in Adjahui (Eguavoen 2020) ${ }^{5}$ and a study on water transport (Kabran and Eguavoen 2019) were integrated into the analysis.

The next section outlines the conceptual orientation of this paper. The empirical Section 3 continues with the analysis of the legal frontiers and the description of practices of place-making and appropriating the reclaim in Soweto/Koumassi Municipality. Section 4 then turns to Adjahui/Port Bouët Municipality, where many Soweto residents had moved.

\section{Waterscapes and the Ownership of Reclaimed Land}

Our research project drew from a number of interdisciplinary approaches, which could be summarised as comparative urban environmentalism (Ernstson and Sörlin 2019) or urban political ecology (UPE) in the city (Cousins and Newell 2019) with a strong emphasis on African urbanism and situational analysis (Pieterse 2013, Lawhon et al. 2013). For this paper, however, concepts and arguments that relate to waterscapes, as well as to the ownership of reclaimed land at waterfronts, were most relevant.

Borrowing from Appadurai's concept of 'scapes' (Appadurai 1990), UPE scholars introduced the concept 'waterscapes' (Swyngedouw 2004) for urban water systems. Others used the term 'riverscapes' later onwards (e.g. Rademacher 2011;

\footnotetext{
5 We documented 591 housing units with their inhabitants and interviewed more than 300 households, who lived in these units. Residential histories of some households are discussed in Sections 3.4 and 4.1.
} 
Follmann 2016) in order to describe and analyse cultural landscapes around rivers, which are socially produced by both humans and non-human actors, such as silt, trees or animals. Waterscapes are landscapes, as well as discursive representations. From this conceptual perspective, natural and socio-political processes that produce waterscapes are not just inter-dependent but inseparable.

In Abidjan, the lagoon and its urban banks could accordingly be called 'lagoonscapes', but we keep on using the more general term waterscape. These lagoon banks are natural, material, social as well as historical and cultural spaces, where land and water meet. These multiple dimensions of the waterscapes are crucial for the analysis. Abidjan is usually referred to as a coastal city. Implications of its waterscapes were under-emphasised in earlier analysis despite the fact that waterfronts were crucial frontiers for city expansion. The reclamation of land from water and waterfront development were and continue to be an important dynamic of urbanisation and the strengthening of existing social-economic inequalities in the city.

Gene Desfor and Jennefer Laidley conceptualise waterfronts as ambiguous spaces, which contain and symbolise nine dualities that contribute to urban contradictions and tensions, including that 'these spaces embody the past and represent opportunities for the future; [...] they are within a jurisdiction but are often outside that jurisdiction's control [...] they are planned and unplanned, [...] they are both natural and artificial' (Desfor and Laidley 2011: 3). We will come back to these particular dualities when discussing the empirical material.

The interdisciplinary engagement of scholars in waterfront debates has shifted the thematic focus from landscape architecture, estate development at watersides and the role for city branding to the historical trajectories of waterfronts, place-making practices, the production of social inequalities and the political contestations behind waterfront projects (e.g. Gidel 2011; Rademacher 2011; Follmann 2016). While waterfronts have attracted people with low incomes to self-build homes on squatted public land in many cities of the Global South, waterfronts are also appreciated by estate developers for their high market values (for an overview, see Davidson 2009). Since the 2000s, the watersides of African coastal and riverine cities have attracted international groups of estate developers who made deals with national governments to rehabilitate waterfronts through long-term leases of large reclaim for estate development. City governments played a supportive role in the implementation of such projects though the participation of city planning authorities and civil society in negotiating the urban form and future outcomes has been low, as seen in Luanda, Lagos or Rabat (Croese 2018; Adjibade 2017; Bogaert 2018). Minimal participation of civil society and local urban experts is also observed in Abidjan where the restructuring of the Bay of Cocody is led by a Moroccan-led consortium and driven by the strengthened political alliance and aspiring economic axis of Morocco and the Côte d'Ivoire. This paper, however, focuses on incremental place-making outside of planned urbanisation, as well as on individual every-day practices.

Adam Grydehøj reflects on the term 'land reclamation', which in his view bears a misleading connotation as reclamation presumes a former loss of land (2015). Grydehøj underlines that the practice typically aims to "extend solid ground out into new frontiers' in 'a sociopolitical process that entrenches existing power structures while circumventing potentially productive social conflict over the use of urban 
space' (Ibid. 2015: 99, 97). In the wider sense, fluidity and temporality are replaced by solidity and fixity. Desfor and Laidley communicate a different understanding when using 'fixity' and 'flow' [which] are dialectically related concepts for understanding waterfront change'. From their perspective, both are 'inherently active and continually produced' (2011: 5). Fixity relates to elements which seem solid, secure and spatially fixed, at least over a period of time, such as buildings, institutions or cultural practices. Flows refer to the continuous forces of change through destruction, creation, combination and separation (Ibid. 2011 referring to Swyngedouw 2004). Through land reclamation, fixed elements of waterscapes that informed practices start flowing. The legitimacy of existing arrangements for ownership, tenure and local authority gets scrutinised and challenged. While a new state of fixity is established, the reclaim is a contested ground, where groups of actors equipped with different assets and bargaining power negotiate their interest.

Waterfronts in Abidjan are public and communal land (see Section 3.1). If land reclamation leads to the transformation of water spaces from communal or public goods into private assets, claims for publicness are hard to make (Grydehøj 2015: 97). 'Land reclaimed within the past decades has been capitalised since conception. It has never been public' (Ibid. 2015: 109). Studies suggest that powerful actors successfully claim ownership, while poor populations living at waterfronts lose out.

The oft-stated justification that reclamation will reduce the density of urban populations rarely transpires, because new densities are produced at the new places. And, as the reclaim was not foreseen in earlier planning, it may disrupt existing urban infrastructure such as transportation or drainage networks (Ibid. 2015). Geomorphological alterations have unforeseen consequences; when sand is dug and transferred to the shores, the depth of the water body is unevenly modified, and habitats undergo change. The relationships of human and non-human actors change with accumulated effects at larger scales. When house builders and estate developers reclaim land, they alter the material relations of land and water in the present, as well as the urban ecology and its ability to mitigate effects from sea level rise or storms in the future. They also intervene in the social and cultural fixity of the waterscape.

\section{The Northern Shore: Koumassi}

\section{Legal Frontiers}

According to the national environmental law, the Ebrié Lagoon is public. Applications for temporal use rights for commercial or private purposes are decided upon at the ministerial level. Political mandates regarding the lagoon are highly fragmented according to the sector. Permits for sand digging, for example, are granted at the ministerial level (Diarra 2015) and thus are decided upon neither by the district government nor by the respective municipalities. Water spaces belonging to the international port constitute a special legal zone (Ibid. 2015: 96f.). The autochthonous population of Abidjan, the Ebrié, who make up around $3 \%$ of the urban population, enjoy customary rights over their territory and are legally handled like rural enclaves within the metropolis, under the leadership of councils of elders (chefferies). If their 
villages are directly located at the lagoon front, their decision-making rights are extended to water spaces:

each riparian village owns a portion of the lagoon in the district of Abidjan, corresponding to the extension of the villagers' lands onto the aquatic area. [...] The various riparian villages are responsible for organising and managing it according to their own rules. (Diarra 2015: 109, translated by author)

Historically, Ebrié customary territory was a communal resource that was given to people in the villages or associated to them. The chefferies approved and documented land transfers. Individual land sales, which have occurred in recent years, are not appreciated by the chefferies who fear a fragmentation of Ebrié territory and their authority thereof. Furthermore, ownership based on purchases of customary land is not acknowledged by the Ivorian government, whose formal application procedure for land certificates, the Arrêté de Concession Définitive (ACD), was set up in 2013. State and city authorities underline that no land title purchased outside the ACD scheme enjoys legal protection by the state. Therefore, purchases from the Ebrié actually transfer temporal land use rights (for farming, fishing or settling) without indicating the period of their validity, while Ebrié communities continue to be the landowners.

Under conditions of an enduring housing crisis in Abidjan, as well as population densification and rapidly increasing land values, contestations over land and water arising from the plurality of law are inevitable. Use rights can be withdrawn by the Ebrié at any time and given to others, and conflicts over Ebrié land are negotiated by the respective chefferies themselves without state involvement. On the one hand, land purchasers external to the communities risk losing out if the interests of the Ebrié are effectively defended. On the other hand, private ownership claims by individual Ebrié are contested by the chefferies who underline the cultural practice of communal ownership. Finally, decision-making rights of the Ebrié are restricted on public land which intersects with their territories.

Natural shorelines with mangrove vegetation, perhaps better described as topographical frontiers that vary with the tides and seasons, were once typical features of the wetlands along the Ebrié Lagoon. Customary territories spread across these aquatic frontiers (see Figure 3), whose extent can only be gauged by a historical comparison of aerial photographs and satellite images. The fixation of such natural shorelines on any map is inevitably inaccurate for it always represents an image of a particular day in a specific season and year.

Based on maritime law, the 25-m zone extending to the natural shoreline (of lagoons) or coastline of Abidjan is state property, irrespective of whether the land falls under the Ebrié territory (Figure 3). Public land along the waterfront cannot become privately owned land under the ACD. However, long-term leases from public authorities to private actors result in a quasi-privatisation of waterfronts. There are numerous examples of quasi-private properties along the banks of the lagoon including private estates, institutions, hotels and commercial areas. When a conflict 


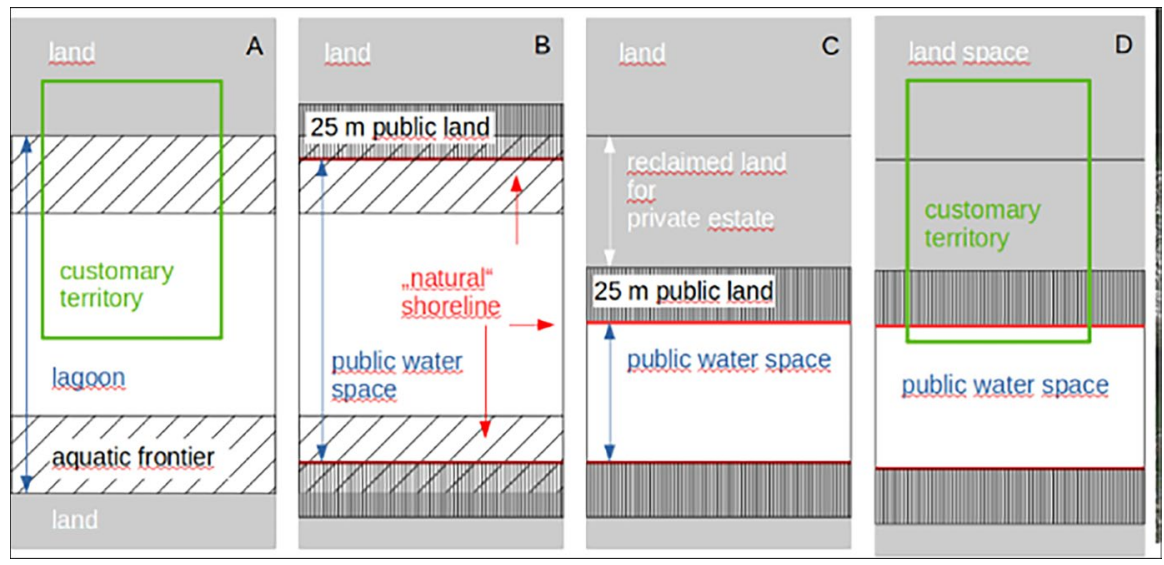

Figure 3 Change of tenure in Abidjan's 'lagoonscape'. Source: author

of interest occurs between Ebrié villages and the district government, as with urbanisation projects, state law is prioritised, and customary land can be expropriated by the state against the payment of a minimal compensation. This is one of the ways in which customary land rights are increasingly being curtailed (Diarra 2015: 140; Shigata 2017).

The conversion of aquatic spaces into land seems to fall into a legal grey zone. ${ }^{6}$ In practice, the $25-\mathrm{m}$ demarcation rule offers room for interpretation because the 'natural shoreline' has no spatially mapped, politically fixed baseline. Through reclamation, shorelines are pushed further into water bodies, and the new shoreline is taken as the marker for the restricted 25-m zone. In this way, public water spaces, public land and reclaimed land are turned into private estates outside of the demarcation zone. This legal loophole is taken advantage of by private house-builders and estate developers, as shown in Figure 3. The schematic indicates how conversion leads to the reduction of public aquatic space. Image D illustrates how the land and water resources are transformed in relation to the unchanging boundaries of customary territory. Accordingly, Ebrié villages along the lagoon have lost communal water spaces and resources but have simultaneously become more relevant land tenure actors at highly attractive construction locations.

Because of their central location within the southern part of the city, Abidjan's waterfronts have also attracted the poor strata of the population with low access to the formal housing market. In the past, marshy and marginal spaces were easily accessible to poor people because there was neither public control nor competition by estate developers because secure land tenure could not be acquired. Such places were usually covered by vegetation and sometimes located under high voltage lines. They were hidden behind industrial buildings, slaughterhouses or cemeteries. By stabilising the ground for self-built homes, low-income groups reclaimed land

\footnotetext{
${ }_{6}$ Mr. Coulibaly, lawyer, 03/2019
} 
though at a much smaller scale and over longer time periods than that achieved by wealthier income groups. Such incremental practices also have accumulative effects in shifting the shoreline further into the water space.

\section{Built with the Feet in the Water: Soweto/Zoë Bruno}

The Bay of Koumassi is located to the south-east of Petit Bassam Island. After the municipal election of October 2018, which resulted in a change of political leadership in the municipal council, ${ }^{7}$ Koumassi underwent a process of urban renewal that included an image campaign (J'aime Koumassi-I love Koumassi), the demolition of illegal buildings and informal shops along roadsides, the construction of a new town hall, infrastructural works such as the rehabilitation of sewage canals and a slum rehabilitation programme. ${ }^{8}$

Soweto and Zoë Bruno are interchangeably used as names for the fast-growing middle-class residential area at the Bay of Koumassi. 'Soweto' is more popular, though local authorities and some enterprises prefer 'Zoë Bruno', perhaps because they feel it will free the area of its negative image as an unplanned settlement. In the current city map, neither of these two names is mentioned. No street is indicated either (CESIG 2014), because the map producers thought it would be irrelevant for the envisaged users of the city map. ${ }^{9}$ The popular narrative about the origin of Soweto recalls a dumping ground near the lagoon. According to a resident landlord:

Bruno Zoë [...] was the first inhabitant here. He worked as a security guard and had no money to build a house [...] He tried to clean the waste and constructed a small wooden hut. [...] Like him, people have arrived here one after the other to live. If there was a little space, it was cleaned and somebody put his little wooden house on it. [...] Bruno Zoë proposed to ask the government to sell land plots [...] and approached the ministry. Because the number of wooden houses was large and it was a precarious quarter, young rascals started attacking people during daytime. This is why the place was called Soweto. ${ }^{10}$

According to the detailed records of Alphonse Yapi-Diahou, who conducted longterm field research in the area, workers evicted for the establishment of the Koumassi Industrial Zone in 1964 were attracted to the place and made it their home. The first settlers, Mr. Zoë and his family, had experienced forceful eviction themselves. After founding the settlement on a bushy marginal land and without negotiations with the Ebrié, Mr. Zoë encouraged people evicted from Koumassi Poto Poto (today Koumassi Remblais) and Port Bouët to come and join him. After 5 years, the high influx of the so-called déguerpis (evicted people) encouraged the first settlers

\footnotetext{
7 The mayor of Koumassi, Ibrahim Bacongo Cissé, is from the leading party RDR.

8 The projet pilote d'Aménagement des Quartiers Restructurés d'Abidjan (PAQRA) started in March 2019 and was implemented in Koumassi Campement, Divo 1 and Divo 2.

9 They envisaged that the map would be used only by tourists and international business people and therefore did not display marginal or slum areas.

10 Landlord in Soweto, 03/2019
} 
to invest in rental housing. Mr. Zoë allocated building plots without charge and kept records about the identity of the house owners and their properties (Yapi-Diahou, 1984). He became the first leader of the settlement. Field data suggest that most new residents in the 1980s were evicted from settlements in Koumassi like Campement, Kankankroua or Délégation. ${ }^{11}$ Even the mayor used to advise homeless families to approach Mr. Zoë for a land plot to make a new home for themselves.

Over time, the settlement grew into a larger slum with a mainly young, male and cosmopolite population. ${ }^{12}$ Most inhabitants were tenants. When first surveyed in 1975, 900 people resided in Soweto (Yapi-Diahou 2000: 49). By 1990, the population had increased to around 10,000 (Yapi-Diahou 1990: 26). Unoccupied spaces to build a home became short in supply, and people arriving at the settlement started to fill the marshy shores with waste, sand and even coffee grounds. The situation was described as follows:

In 1979, the newcomers to the settlement [built their houses] a little retracted from the marshy grounds of the lagoon front. But in 1989, after being driven [from their homes] by the construction works of the express way linking Koumassi North-East to the Boulevard Giscard d'Estaign, most [new] inhabitants fell back on the unoccupied marshy interstices within the settlement [at the shoreline]. Although narrow and expensive to reclaim, opportunities existed. The settlement did not really have its feet in the water yet, and it was still possible to accommodate a few more needy people on the bank of the lagoon. (Yapi-Diahou 2000: 50, translated by author)

Zoë Bruno is marked on the land use map from 1986 as 'legally precarious housing on private housing estate or temporary resettlement area' (Antoine et al. 1987, translated by author). Other populated waterfronts in southern Koumassi appear on the map without annotation. Soweto, however, was not an official resettlement site. Instead, the déguerpis squatted underused public land and at a later point, when evictions continued, began to encroach the mangrove swamp at the shore of the lagoon. Just before the construction of the Boulevard Antananarivo in 1989, a map was produced (reprinted in Yapi-Diahou 1990) that shows how the settlement was surrounded by the depot and workshop of the public transport company, a school compound, a saw mill and factories, all of which were fenced (Figure 4$)^{13}$.

At this point in time, areas below high voltage lines were exempted from construction and offered a corridor along which workers of the local brick manufacturer established a settlement called SOBRICI. Along the banks of the lagoon, the map shows a large area covered with 'bush land' standing for mangroves which were later incrementally reclaimed. It was the marginality and inaccessibility of the space that on the one hand attracted Mr. Zoë and his followers and on the other hand made it unattractive for estate developers. Investment in land reclamation became

\footnotetext{
11 The latter two settlements do not exist any longer.

12 By this time, the population was mainly born in other parts of the Côte d'Ivoire or other West African countries with a large share of Mossi from Burkina Faso (Yapi-Diahou 1984: 21).

13 Sources: Yapi-Diahou 1990: 27; Koffi et al. 2015: 139
} 
the foundation of the settlement's right to exist (Yapi-Diahou 1984: 154) and the cornerstone of the residents' attachment to the place.

Soweto was tolerated for many decades by Koumassi's succeeding mayors and the district government. Yapi-Diahou described the place as a universe of precarity and indigence (1990: 26). The settlement was formalised in the context of a World Bank-funded amelioration and restructuring programme which, beginning in 1995, built a road connecting Boulevard Antananarivo with the lagoon front where a ferry quai had evolved, as well as two sand roads leading inside the eastern part of the settlement. It became a regular quarter of Koumassi locally administered by a council of inhabitants. While single-storey courtyard houses were built without foundation, multi-storey apartment houses (immeubles) required proper foundation work due to high water tables. Thus, every building lot was first filled with rubble and sand. Living conditions remained precarious even though the programme provided a connection to the electricity grid and water supply network, as well as a public primary school and a community health centre. Private initiatives completed this meagre offer of services. Despite this, many households continued to buy water from vendors, and about half of the population relied on illegal electricity connections (Koffi et al. 2015). The map from 2013 (see Figure 4) shows that the original western road divided the settlement into two sectors. Courtyard houses on non-parcelled land dominated the part to the west of the road, while the eastern part had undergone parcelling in 1995, which ended where the shoreline of the lagoon used to be (Ibid. 2015: 139). By this time, the Bay of Koumassi was heavily polluted by industrial sewage and dense settlements along its shores (Pottier et al. 2008: 175).

During field research in 2019, the construction of immeubles, shops, buildings of public use and two hotels (see Figure 5) suggested formalisation far beyond the parcelling scheme of 1995. The area to the south and east had been parcelled, bought and built upon by private actors with the hope that urban infrastructure (water, electricity, sewage and roads), as well as the successful application for the ACD to secure private land ownership, would follow later. The future receipt of land certificates remained individual speculation. A resident landlord owning two large immeubles outside of the 1995 parcelling scheme expressed confidence about his house ownership as follows:

It was not the municipality that did the parcelling. But it happened with their approval. There were economic operators who brought the diggers with the approval of the mayor's office and the land owners who are the Ebrié. [...] There are no land certificates yet. But it is approved. People build several floors and then seek formal approval [i.e. apply to the ACD when the zone is a regular quarter and opened for the ACD process]. ${ }^{14}$

Inhabitants and investors bought land plots from the Ebrié under the customary regime and constructed homes and immeubles outside of the 1995 parcelling scheme. Courtyard houses were demolished in order to make space for the new buildings. High demand in rental housing encouraged further land reclamation in

${ }^{14}$ Landlord in Soweto, 03/2019 

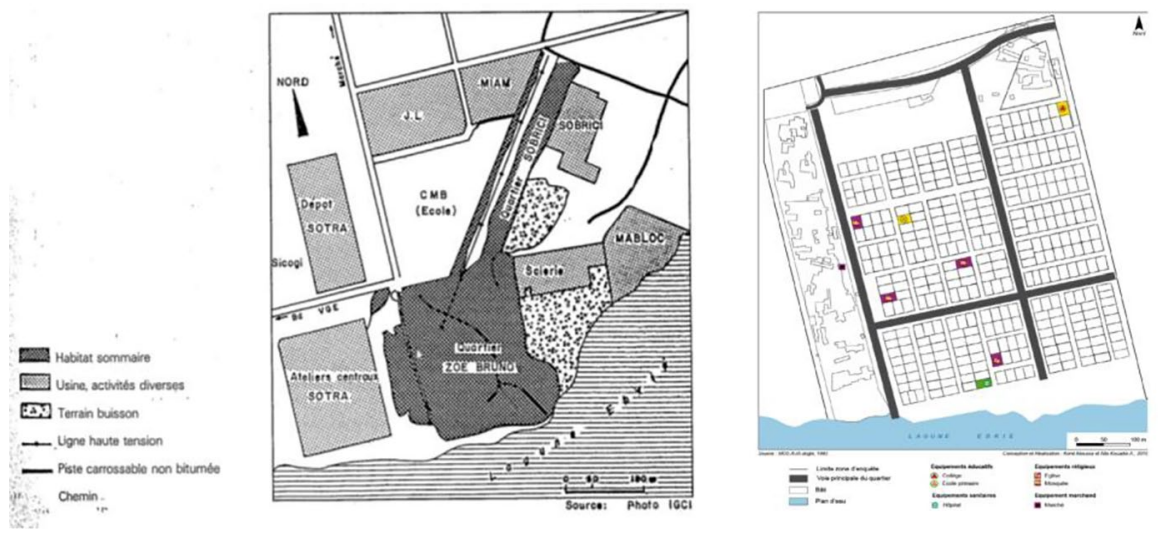

Figure 4 Location and extent of Soweto/Zoë Bruno at the end of the 1980s (left) and in 2013 (right). Sources: Yapi-Diahou 1990: 27; Koffi et al. 2015: 139

order to extend the surface of marketable land to the south-eastern shore. A new area, Soweto Remblais, was created with water and sand pumped from the lagoon (Figure 5). Marcory Remblais and Koumassi Remblais (originating from French remblayer, to fill), now regular middle-class quarters on solid ground, both evolved in a similar way. During field research, diggers next to Soweto Ferry Quay provided sand for construction and reclamation (Figure 5).

Until 2013, a single ferry line operated across the Bay of Koumassi to ensure the transport of teachers to Adjahui-Coubé (the village of Adjahui). With rapid population growth in Adjahui, private actors quickly established 20 more quays servicing 11 ferry lines (Kabran and Eguavoen 2019). An additional three quays were established at Soweto Remblais. Soweto's residents were seen enjoying the new wide space reclaimed from the lagoon, playing football, going for walks or relaxing at bars by the water, before immeubles will be constructed upon it. Their practices give some idea of how a beach would eventually be used if it was a protected public space (see Figure 6). Reclaim and urban renewal extend to the adjacent waterfronts of Bia Sud, Sito and behind Camp Commando near the Koumassi Weir (see Figure 2).

\section{The Appropriation of the Reclaim: Camp Commando and Koumassi Sito}

Confronted with media observations of large-scale land reclamation and construction at the Bay of Koumassi, the director of AGEF (the national agency of land management) claimed in 2019 that investors were acting illegally because they had not requested a building permission. In any case, no such permission for construction could have been issued to them by his office. This was so because estate developers would be unable to present an ACD awarded by the state, because they were acting in the 25-m demarcation zone. The AGEF director explained that a distance to the shoreline had to be kept and that no rule exists that permits this enterprise. Finally, he wondered why the municipality of Koumassi had not intervened: this 


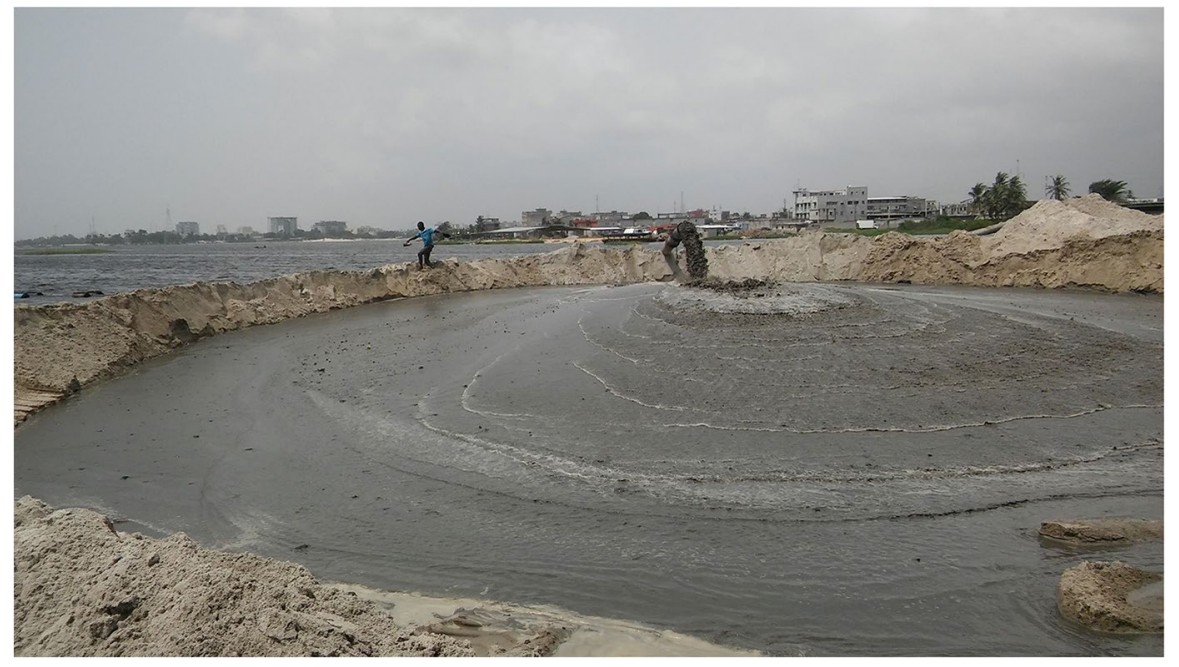

Figure 5 Land reclamation at Soweto Remblais with water and sand pumped by digger boats. Source: author

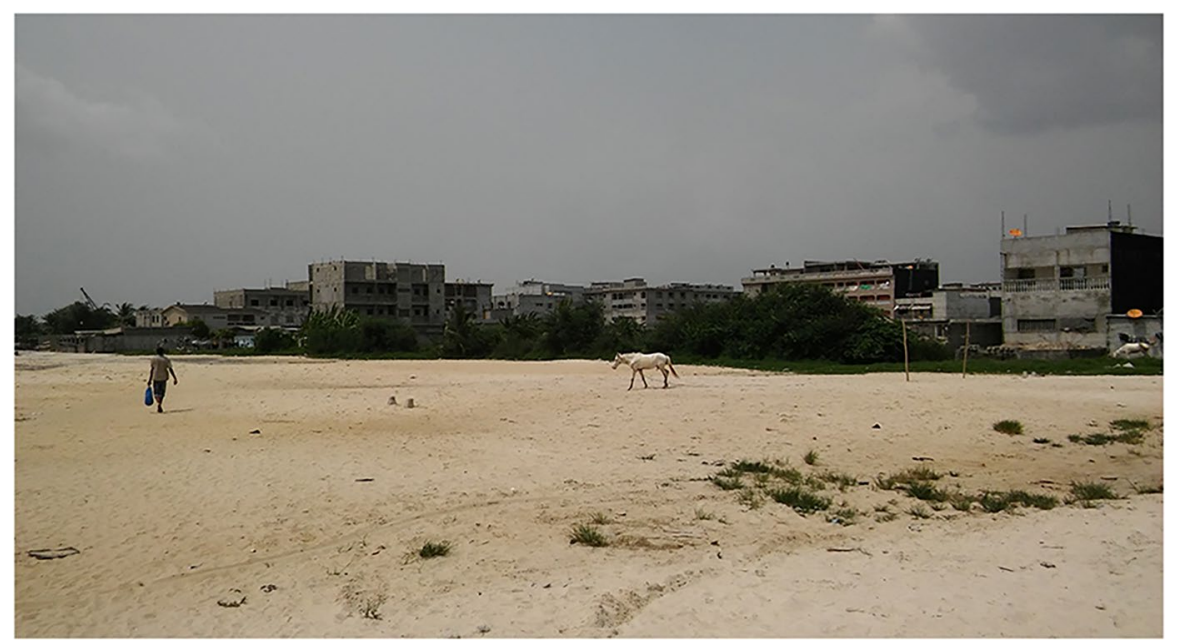

Figure 6 Beach at Soweto Remblais in 2019. Source: author

was unbelievable! ('Ça c'est le comble'). ${ }^{15}$ In the same media report, the advisor to the mayor defended the reclamation by explaining that the municipal committee for the slum rehabilitation would give the reclaim to people who needed to be relocated in the course of rehabilitation works. He said that the mayor's office was

15 Mr. Kouamé, quoted in RTI info (2019) 
busy organising the required building permits. The mayor's advisor assured the journalists:

We have initiated an operation to control all corners of the waterfronts. Investors and even the [residents of the] quarters, which are precarious at the moment...we will make sure that they remain within their limits [i.e. do not enter the 25 metres zone]. ${ }^{16}$

Some interview partners explained the 25-m demarcation rule to us before illustrating that rule and practice eventually differ. The first statement was given by a landlord:

The land is limited here.[...] You need to reserve 25 metres and are not allowed to exceed. [...] Behind the house, you cannot exceed into the 25 metres zone. You can [only] make a small garden or hut for taking some air. [...] All watersides are like this. It is like this in the plans. ${ }^{17}$

The second quotation by the village chief in Adjahui-Coubé hints to the fact that shorelines remain in a state of material flux and may endanger the stability of buildings. Living at the opposite shore, he closely and critically observed what happened in Soweto Remblais:

people [authorities] do not come into the field to see. They are in the office. They sign and that's it. [...] But most of those [house builders] who are well off [...] don't want anyone to come after them. They always want to be on the waterfront. So the land plots are glued to the lagoon directly [...] The state has requested the ACD [from the house owners]. You have to respect the 25 metres or the plan will not be accepted [by the authorities]. But it's not only 25 metres. You have to give at least 50 metres [...because] where the 25 metres ends, the water can take the land again. ${ }^{18}$

Estate developers and wealthy private investors were motivated by the 'waterfront estate logic' which promises higher returns (Davidson 2009). They hired sand digger boats to quickly establish new solid grounds and realities. Even though they might be able to show a valid permission for sand digging by the respective ministry, their construction activities happened outside building regulations as well (and were thus similar to poor people's building practices). Immeubles, however, were perceived by the municipal council as contributions to the urban renewal of Soweto, Koumassi and Abidjan, which was not the case with single-storey courtyard houses. Authorities tend to treat immeubles with a laissez-faire attitude, perhaps because they better mirror their own vision of a modern city.

The situation of less well-off house builders is very different. In 2018, our research team was called to Koumassi Sito where we found about a dozen demolished solid courtyard houses (see Figure 7) and two desperate former landladies

\footnotetext{
16 Quoted in RTI info (2019), translated by author

17 Landlord in Zoë Bruno, 03/2019

18 Member of chefferie of Adjahui-Coubé, 04/2019, translated by author
} 


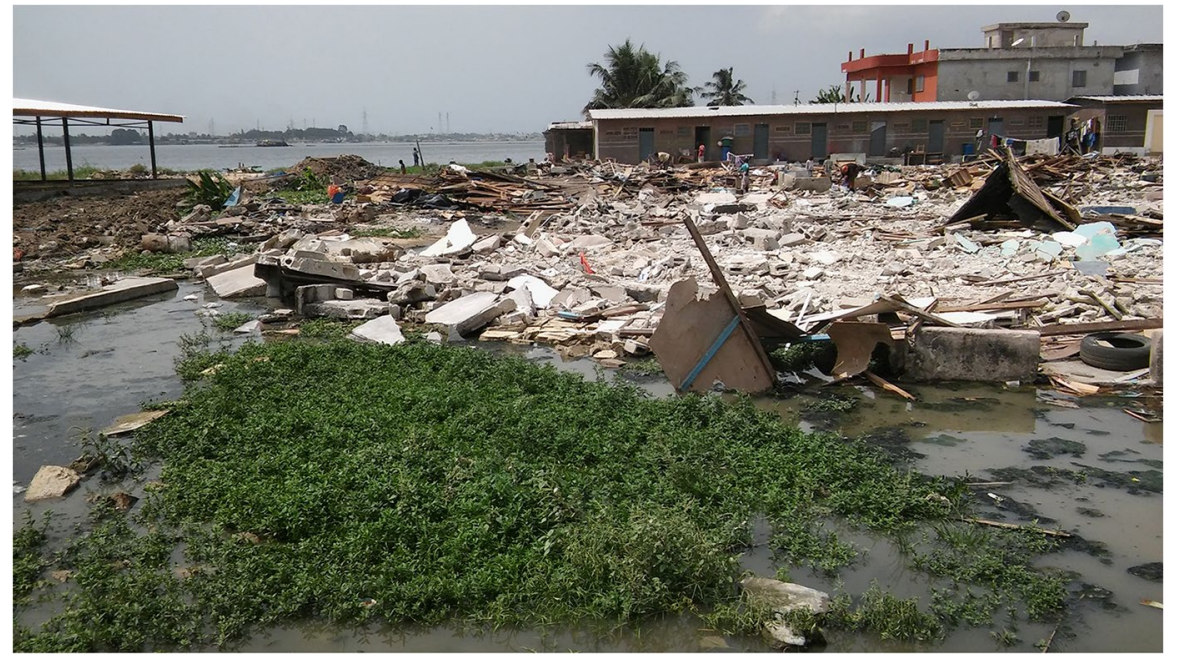

Figure 7 Demolished courtyard houses in Koumassi Sito. Source: author

who explained to us their dilemma. One of them, an old woman, came every day to the site since demolition because she hoped that someone would advise her how to claim back her lost property. Her neighbour recalled how they had arrived in Koumassi Sito:

My husband and I arrived here in 1992 when the place here was marshy. [...] The land was empty but is was owned by an Ebrié. He rented it out to us for construction. While we were here, we have stabilised the land near the swamp. My neighbour [the old woman] arrived a few months after us. [...] This is how we have reclaimed the area and it became land. Some years later the man sold his land. We don't [actually] know whether he sold the land but we were asked to leave the place that he had given to somebody else. Since the land was not ours, we returned it to him.

We moved here because this side was reclaimed. [...] It was a Beninese seaman who had reclaimed the place [...] After a few years [in 2012] the man told us that the place had been divided into plots. It was he himself who had paid the fee for this. He also made the road that you see there because the other side was closed. When he made the road, he asked the neighbours to help him. [...] The old woman [her neighbour] has contributed money. ${ }^{19}$

New settlers at Koumassi Sito acknowledged the authority of the Ebrié and earlier settlers. They sought arrangements over land use with them. Swamps were stabilised and became residential places. Later, dwellers built courtyard houses and

${ }_{19}$ Evicted landlady in Koumassi Sito, 03/2018 
accommodated tenants. Private investment in land reclamation, informal construction and the improvement of infrastructure paid off as new places became homes and rentals from which regular income could be generated by house owners and Ebrié landowners alike for over the past 20 years. The tenure arrangement and power relations were fixed.

Owners of houses on the reclaim were aware of their weak bargaining position with the Ebrié. Encouraged by the vague idea that land reclamation justifies property claims, they further invested in reclamation and registered land plots at the Ministry of Economy and Finance (its department Direction Générale des Impots). Though many of these residents originate from other West African countries or other regions of the Côte d'Ivoire, they relied on the Ivorian state for accomplishing tenure security and the protection of their assets in the city and in return paid fees and tax obligations. ${ }^{20}$ Around 5 years after having registered the reclaim in the land register, the house owners were asked by the district authorities to halt their contributions and to instead pay taxes to the Ebrié. Soon after, new desires arose around the reclaim:

To our great surprise the Ebrié came and claimed the land by saying all of Abidjan is owned by them. Even though it looks like this [now], this was not land. It was water that we reclaimed. They said that the land was theirs and that we had to pay in their hands. That they need to give us a land plot to buy. The [Beninese] man told them that he already had done the parcelling. [...] [but] the Ebrié told us that they would divide the land into plots because the parcelling that we had was not fair. We should not have followed the old regulations, the plots would be too big by any means. [...] They returned five to six months later to tell us that they had sub-divided the land. [...] They have not shown us the papers until today. [...] Surely, when they went to the cadastre, they must have seen that the sub-division had already been done. ${ }^{21}$

The house owners still felt certain about themselves because they possessed a document issued by the ministry ${ }^{22}$ and they had paid the government and the Ebrié as they were told to do. Yet in November 2017, they received an official notice from the mayor of Koumassi that their houses would be destroyed because they were built on public land. Our interview partner further explained how often she had been to the town hall in Koumassi only to be dismissed each time. The affected house owners addressed a joint letter to the mayor claiming ownership of their residential plots. The woman suspected that the mayor in agreement with the Ebrié had sold the land to a Lebanese investor who wants to build a market. The mayor had later ensured that the house owners could stay on another part of the land. After the elections, the mayor changed. The personal covenant of the former

\footnotetext{
${ }^{20}$ Côte d'Ivoire is the country with the highest number of stateless persons worldwide; most of them live in Abidjan. They and foreigners are excluded from legal land rights (RLS 2020).

21 Evicted landlady in Koumassi Sito, 03/2018

22 Dossier de calculs/dossier techniques de morcellement (technical file of parcelling), including a plan of site
} 
mayor was useless. Forceful eviction and the destruction of their properties were executed by district authorities in mid-2019.

The house owners felt betrayed and sold. Properties were lost. No compensation was paid. They had neither been aware of the $25-\mathrm{m}$ demarcation rule nor of the legal and customary implications of land reclamation. They found it very difficult to believe that other actors could successfully claim land that they had created from water. Before the eviction notice, for as long as 25 years, the demarcation rule was irrelevant to them because breaching had not been sanctioned when local authorities were weaker before and during the civil war. This changed after 2011, when the district and municipal governments were strengthened and legislation was revised. No form of legal action against the demolition had any chance of success. The experience of arbitrary governance (from the women's perspective) went hand in hand with the contempt that more powerful actors (customary landowners, the municipality and rich investors) had formed an alliance against them. Land, which they had reclaimed with their money, was being commercialised by others. They felt like right-less citizens.

\section{The Victims of Fraud: Koumassi Campement}

Waterfront tenure is characterised by legal pluralism which results in the limitation of decision-making rights over land use for all actors. This illustrates well the jurisdiction issue mentioned by Desfor and Laidley (2011). The municipality, for example, cannot intervene on customary territories against the will of the Ebrié. The Ebrié cannot fully decide over their territories if these overlap with public land. Land cannot be officially parcelled if the district government has not acknowledged the place as a regular quarter of the city. At the same time, there is high pressure on land resources and demand for building plots which encourage risk-taking practices. Different interest groups feel in the right about their individual claims based on different perspectives towards the law. The Ebrié were rightfully deciding over their customary territory. The individual Ebrié landowner in the woman's account had received the plot from his community and could rightfully rent out use rights over land and water spaces. The claims by the state based on the 25-m demarcation rule are correct. The municipality, which finally decided to put the legal rule into practice and to sanction the breaching of maritime law, also acted rightfully. The house owners in Sito perceived themselves as rightful landowners based on government papers. Unfortunately, and unbeknown to them, their legal papers were invalid documents. The ministry should not have given them any document because they settled at the waterfront.

This confusing situation can easily be exploited by reckless investors or fraudsters as the example given below shows. Here, an investor mimicked an eviction by the district authorities to create irreversible conditions on the ground to his own benefit, because the house owners, who lived on reclaimed land in Koumassi Campement (a precarious quarter at the lagoon front; see Figure 1) and within the demarcation zone, knew that their ownership claim to their building plots had no legal backing. The eviction was reported to us by a former house owner, who ran 
a small shop for TV equipment. We met him during the ethnographic census in Adjahui. Desperate, he approached the mayor of Koumassi for support after his house was demolished in Campement:

I lived in Koumassi Campement. Today it is difficult for the state to destroy such a quarter. They have come to say that those who are at the watersides, less than 25 metres, would have to relocate. It was not the state, it was an individual who came to brutalise us like this to destroy the corner. I have built my house which was demolished. The person [...] said that the place was his. Afterwards, the mayor said that this was not true. But the house was already gone. One could not do anything. The person had money. We don't have money.

During the rainy season, the state may decide to demolish certain sites [in the context of a public disaster reduction programme, under a prescribed legal procedure including timely and public announcement]. But individuals benefit by pretending to act for the state. [...] The man [who demolished our house] told us that he had papers signed by Houphouët Boigny [the Ivorian president from 1960 to 1993], which made him the owner of the entire waterside.

The eviction was not [correctly] announced. On Sunday they said that they would destroy the site on Monday. They came with machinery and the [fake] gendarmerie on Monday morning between 3 and 5 o'clock. [...] When they finished, we took our belongings and directly came to Adjahui. We had no other place to go to. There were other déguerpis who stayed at the waterside another month because they had no money. ${ }^{23}$

This example illustrates several cultural practices. The shop owner built a courtyard for this family nearby the water and by stabilising a shore as the inhabitants of Soweto and Koumassi Sito did. In his view, he had the right to stay until the state or district government, who owned the bank of the lagoon, would claim it back from him. He relied on the fact that such an eviction would be timely and publicly announced as prescribed by law and that this would eventually never happen because of the laissez-faire-attitude of the authorities.

Also, fraud follows a pattern: announced on a weekend, the fraudsters ensured that the house owner would not be able to reach anybody in the municipal office for confirmation or negotiation. The demolition was quickly announced and implemented not leaving any room for manoeuvre. House owners were taken by surprise. Yet, if the investor respected the demarcation zone for his own construction, the municipality would not see the need to intervene. And, of course, they would not protect house owners who settled illegally in an area. The removal of unplanned housing on the waterfront by any means, even fraud, ultimately increases the value of the private waterfront estate. But house owners and tenants with low incomes would lose their home and assets in just a few hours making them even more vulnerable to poverty.

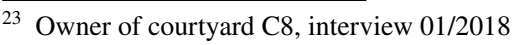




\section{The Southern Shore: Port Bouët}

\section{Encroachment of Waterfronts: Adjahui}

There are strong parallels between the evolution of Soweto and slum growth in Adjahui, which belongs to Port Bouët Municipality. Land tenure on the peninsula is characterised by the territories of three Ebrié villages (including a land conflict between two of them), the 25-m demarcation rule and a decree from 1979 which declares that the area serves as a reserve for the expansion of the international airport. The entire land on the peninsula except the village Adjahui-Coubé is a public utility, which was given on a long-term lease to the private airport authority, which subsequently transferred land use rights of some plots to some of their employees for housing and farming.

Rapid urbanisation began in Adjahui with the forceful eviction of the residents of Moussakro at the Airport Road in 2011. The displaced déguerpis negotiated access to land with the Ebrié chefferie of Ancient Koumassi, an Ebrié village located at the weir of Koumassi. The man who led the déguerpis to Adjahui became chief of the new settlement. He kept records and organised everyday life, as well as the influx of people during the first few years. The population influx was enhanced by a wave of forceful evictions at Atlantic waterfronts in Port Bouët in 2013/2014 and Abbatoir in 2017/2018 (see Figure 2). No relocation sites were made available by the district government who conducted these evictions. However, the municipal council of Port Bouët supported the déguerpis to find housing in Adjahui.

A major part of Adjahui was built on solid ground. Family courtyards were soon complemented by low-cost rental housing, and the population influx resulted in a high demand for building plots. The shores were stabilised for construction without much extension into the lagoon. House owners founded the Union des Propriètaires des Lots à Adjahui-Coubé (UPLAC). This association negotiated the demolition of courtyard houses located within the 25-m demarcation zone in 2019, because to most of its members, obedience to the law was important. However, their main motivations were the widening of roads to enable access to the trucks of the electricity company and a strong attempt to 'make the quarter move into legality' by ensuring conformity to formal building regulations. From 2017 onwards, with speculative investment in low-cost housing by entrepreneurial landlords mostly from Koumassi or abroad (Eguavoen 2021), the peninsula and shores at the Bay of Koumassi were turned into building plots. Waterfront locations were secured by walls suggesting future investment in villas or hotels. Along the shoreline to the north, north-east and south of the peninsula, we found markers of plot boundaries reaching far into the swamp and the lagoon (Figure 8).

Land use change, urbanisation, population growth and urban sprawl in Adjahui happened much faster than in Soweto/Zoë Bruno, because the destruction of existing low-cost housing in Koumassi and Port Bouët over the years accelerated the problem and led to the concentrated intra-urban flows of poor strata searching for housing. According to estimations based on the ethnographic census, there were already 60,000 inhabitants in mid-2018, while the population influx continued (Eguavoen 2020). 


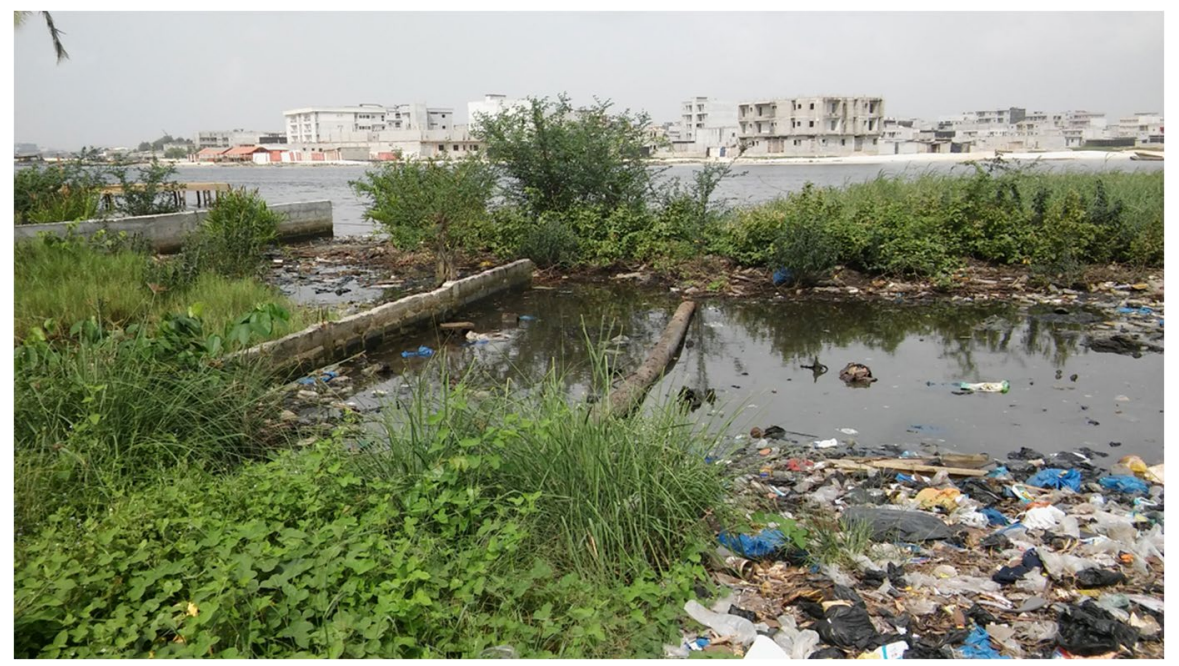

Figure 8 Incremental land reclamation in Adjahui with Soweto Remblais in the background. Source: author

\section{Stranded in the Growing Slum: Adjahui}

Self-built family and rental courtyard houses in Soweto and Bia Sud were demolished for immeubles and new infrastructure. Other families were evicted by the district government according to the 25 -m rule. Some house owners and landlords were compensated for the loss of their courtyard houses by investors, who bought land plots outside the 25-m zone. However, all tenants lost their homes, and many had difficulties reclaiming the security deposit they had paid when entering the rental contract. To find a new home was a challenge to former house owners and tenants alike.

Many of the déguerpis moved to the opposite side of the bay. During the ethnographic census, 12 of 24 households who had arrived from Soweto, Bia Sud and Sito reported that they had left because their house was demolished or destroyed (in 2013/2014 or 2017/2018), including three households who suspected arson by investors. Three households had already experienced loss of housing due to demolition or forceful eviction before moving to Soweto and Bia Sud. Eight households had searched for opportunities to establish an independent household but found no affordable rental housing in Koumassi. Seven households could not pay the high security deposits there, and poverty prevented another eight households from staying on in Koumassi. ${ }^{24}$

In Adjahui, the old woman from Koumassi Sito, whose home and rentals were demolished, rented a small solid room, which she shared with her grandchildren.

\footnotetext{
${ }^{24}$ We counted 66 different former residential places (quarters) in Abidjan ( $n=278$ households). Thirtyfive households had arrived from Koumassi Campement (Eguavoen 2020).
} 
The TV shop owner, who became victim of a fraud in Campement, became a tenant for a while but had succeeded in saving money to build a wooden courtyard with a small TV shop in Adjahui, which his family shared with their tenants. He became a landlord, while his relatives from the family courtyard in Campement had found rental housing in various quarters of Koumassi.

The residential stories we documented during the ethnographic survey were told by residents who live on low incomes although pursuing regular work. Many of them experienced the move to Adjahui as involuntary fate and were driven by affordability and, in the case of young adults, the freedom to establish an autonomous household. Interview partners had experienced loss. They were resigned to their fate and thus willing to sacrifice their quality of life for an interim period: deteriorating conditions of everyday life, the humiliation of losing the status of landlord and becoming a tenant or the temporal dispersal of the family across several municipalities Interviews revealed, however, that many households, unable to economically recover from their loss, got stuck in Adjahui. ${ }^{25}$ Homelessness in Abidjan is often hidden. Before sleeping on the street or at the beach, people become free lodgers with friends and relatives even under precarious and cramped housing conditions, such as in Adjahui. The ethnographic census documented many such examples.

\section{Losing the Communal Space: Adjahui-Coubé}

The distance between Soweto Remblais and the opposite shore at Adjahui has reduced, by land reclamation, to a passage of just $50 \mathrm{~m}$. The destruction of the lagoon's bed by sand mining and the disconnecting of the different bays of the lagoon have a negative impact on the lagoon ecology, which depend on the exchange of sea and sweet water. The few remaining mangrove patches struggle with the altered environmental conditions. The negative impact of sand digging, land reclamation and pollution on fisheries and crab stocks is obvious to the fishermen of the area. In 2019, thousands of dead fish washed up on the bank of Adjahui, ${ }^{26}$ presumingly because of low oxygen levels or pollution in the water. Uncontrolled reclamation blocks the drainage, especially if plastic waste is used for land reclamation. Flooding is a major problem in Koumassi but, as yet, less so in Adjahui although belts of solid waste assemble at the shores.

The riverine Ebrié communities have a strong attachment to the lagoon because the livelihoods of the villagers were and still are economically and culturally tied to the water space. The village Adjahui-Coubé was founded around 1890. The community lived on fishery and agriculture, which ended when rapid urbanisation set in. The chefferie of the village, which is now surrounded by the slum, was concerned about decreasing fish stocks, deforestation of mangroves and, on the peninsula, the loss of wild animals, severe environmental pollution and the safety of the inhabitants. The chief told us 'The children used to swim... But today the water has become

\footnotetext{
25 There is a bias because we could only interview households who lived in Adjahui. We did not come across any story about a household who moved out.

26 www.coteivoire.news, 31.07.2019, Mort suspecte de poissons à Adjahui: les conclusions de l'enquête enfin connues
} 
deep. A child can drown easily... ${ }^{27}$ hinting this way to the growing disconnection of Ebrié livelihoods to the lagoon. Despite enjoying customary decision-making rights over the bays in front of their villages, the Ebrie chefferies cannot control sand mining and large-scale reclamation. Instead, they helplessly watch as the communal water space is lost. Their political weight on reclaimed land has increased, however, because they need to be consulted in questions of tenure and use. If reclaimed land outside the demarcation zone would be registered under the ACD as private property, customary rights of the Ebrié community and their communal water spaces and resources were finally lost.

\section{Conclusion}

Lagoonal waterfronts in Abidjan are waterscapes, which assemble various aspects: an understanding of customary ownership with their related communal practices; the naturally and socially produced watershores, reclaimed building plots and the legally defined but spatially unfixed 'natural shoreline'; the histories of different groups of residents, which reflect the demographic flows and wider history of urbanisation in Abidjan; as well as the changing discourses about tenure and building practices in unplanned settlements.

The study illustrated the motivations of actors who reclaimed and appropriated the banks of the lagoon, which were in many cases marginal lands under public ownership. The state always legally claimed ownership of the shores but in practice allowed quasi-privatisation of watersides under long-term leases for institutions, businesses and wealthy Abidjanais. At the waterfronts, low-income groups and evicted people erected unplanned settlements, which were tolerated by the national and district governments, as well as by the municipal councils. Inhabitants used the spatial niches by the water because they were unattractive to estate developers. Building on the swampy ground posed a challenge. No land certificates could be obtained there.

The analysis of place-making practices in Soweto and Adjahui shows a pattern, which can be generalised to many waterfront settlements in Abidjan: initially, first settlers took a leadership role for the spatial and infrastructural development of the unplanned settlement and managed the population influx. Private huts were expanded over time to family courtyards and rentals, which attracted even more people. Though land use was not based on legal ownership, manifold strategies existed to secure a housing plot over a long period of time, such as customary land transfers, individual arrangements with neighbours, buying land in the informal market, reclaiming water spaces for building grounds, registration with public authorities or simply living at the shore or renting out places there. Although tenure was highly insecure in the legal sense, use rights, house ownership and local power relations in these waterfront settlements were fixed for decades despite the fact that buildings, residents, local arrangements and the spatial form constantly changed. This holds

27 Member of the chefferie of Adjahui-Coubé, 04/2019 
true for the shoreline as well. Because it was incrementally reclaimed, it became more spatially fixed than the natural shore line, which was in flow due to tides and seasons. Though inhabitants increasingly entered the water space and the lagoon, the material condition of the settlement seemed stable because the process took place over many decades.

In the case of Soweto, we observed how fixity started to be replaced by flows under the urban renewal scenario. Estate developers and wealthier private investors began speculating on the legalisation of the waterfront neighbourhood. They bought land on the informal market and pushed the construction of immeubles, even though there was neither infrastructural provision yet nor could they yet apply for land certificates. These actors also reclaimed building plots because of the high water table. Some of them tried to maximise the surface of the building ground by professional sand digging. With these new groups of actors, existing tenure arrangements and house ownership became scrutinised. While some Ebrié landowners benefited from lucrative land sales, earlier tenure arrangements were cancelled. This led to the expulsion of low-income groups from the area. The shoreline was quickly pushed to the water space and public and communal water spaces were lost. This process happened rather unnoticed and without provoking local actors or organisations to rise claims for publicness.

Although the historical and present practices of reclaim and land appropriation differ in scale and technology, they are in fact similar. Different seems the response by public authorities against breaching building regulations and the $25-\mathrm{m}$ demarcation rule. The district government evicts courtyard houses but tolerates the immeubles at the shores of Koumassi. Here, the time dimension is important, as authorities tolerated reclamation and illegal construction in unplanned settlements before (Soweto) and tolerate them at present (Adjahui). They might tolerate illegal estate development today but eventually sanction or legalise the buildings in the future.

Since 2011, with the strengthening of urban governance in Abidjan and its municipalities, the breaching of rules is more effectively sanctioned. Unplanned urbanisation, which is an expression of exclusionary political systems, may undermine the authority of public agencies, the legal system and modern democracy itself (Rocco and Ballegooijen 2019). It is therefore important to make the rules known to everybody and to consequently apply sanctions fairly irrespective of whoever it is that breaks the rules. Lack of transparency and laissez-faire attitudes accelerated the problem of urban inequalities, slum growth and expulsion. It triggers the further exploitative reclamation of communal and public water spaces. Due to overlapping mandates, public authorities have not efficiently sanctioned these exploitative practices. Sanctions though are urgent because the process of reclamation is irreversible. Urban policy at waterfronts in Abidjan suffers from an utter lack of awareness towards the protection of public spaces and the ecosystem services provided by the lagoon, such as ventilation and cooling effects to the city, a source of local food and income, culturally meaningful spaces, recreational spaces as well as local water security.

Legal plurality in tenure and the customary tenure system have historically grown from the history of the city and form conditions that need to be included in urban policy. One policy option would be to protect existing public spaces by the water even if they have been converted from water to land. To this end, a deadline would 
have to be set by the city government on which a fixed shoreline and the 25-m demarcation zone in Abidjan would be clearly defined in maps. Any reclaim beyond that line would in the future remain public and communal property. Such a policy would not prevent future reclamation and construction but would decrease the legal loophole, discourage exploitive practices and ensure that the district government, municipal councils and Ebrié chefferies would remain in full control.

Acknowledgements I am very grateful to the two anonymous reviewers, Joe Hill and members of the working group geographical development research at the University of Bonn for reviewing earlier versions of this paper. I would like to thank the research assistants Fulgence Kouame and Pauline Attemene, as well as the consultants of the project. Estelle G. Kabran drew our attention to the demolitions in Koumassi Sito. Eugene Konan Konadio provided a map to the research project with an overview on waterfront development from 2008 to 2018.

Funding Open Access funding was enabled and organised by the University of Bonn (Projekt DEAL). The research project Waterfront Metropolis Abidjan (2017-2019) was funded by the Deutsche Forschungsgemeinschaft (DFG, German Research Foundation)_EG 381/1-1.

\section{Declarations}

Competing Interests The authors declare no competing interests.

Open Access This article is licensed under a Creative Commons Attribution 4.0 International License, which permits use, sharing, adaptation, distribution and reproduction in any medium or format, as long as you give appropriate credit to the original author(s) and the source, provide a link to the Creative Commons licence, and indicate if changes were made. The images or other third party material in this article are included in the article's Creative Commons licence, unless indicated otherwise in a credit line to the material. If material is not included in the article's Creative Commons licence and your intended use is not permitted by statutory regulation or exceeds the permitted use, you will need to obtain permission directly from the copyright holder. To view a copy of this licence, visit http://creativecommons.org/licenses/by/4.0/.

\section{References}

Adjibade, I. (2017). Can a future city enhance urban resilience and sustainability? A political ecology analysis of Eko Atlantic city, Nigeria. International Journal of Disaster Risk Reduction, 26, 85-92. https:// doi.org/10.1016/j.ijdrr.2017.09.029

Antoine, P., A. Dubresson \& A. Manou-Savina (1987). Abidjan coté cours: Pour comprendre la question de l'habitat. Paris: Kathala.

Appadurai, A. (1990). Disjuncture and difference in a global cultural economy. Theory, Culture \& Society, 7 , 295-310. https://doi.org/10.1177/026327690007002017

Bogaert, K. (2018) Globalized authoritarianism: Megaprojects, slums and class relations in urban Morocco. Minneapolis: University of Minnesota Press

CESIG (2014). Abidjan: Plan guide. Echelle 1/25.00. 2ème édition. Abidjan.

Croese, S. (2018). Global urban policy making in Africa. A view from Angola through the redevelopment of the Bay of Luanda. International Journal of Urban and Regional Research, 42(2), 198-209. https://doi. org/10.1111/1468-2427.12591

Cousins, J.J. \& J. Newell (2019). Urban political ecologies of and in the city. In Schwanen, T. \& R. van Kempen (Eds.), Handbook of urban geography (pp. 33-46). Cheltenham/ Northampton: Edward Elgar Publishing.

Davidson, M. (2009). Urban geography. Waterfront development, In Thrift, N. \& R. Kitchen (Eds.), International encyclopedia of human geography (pp. 215-221). Elsevier.

Desfor, G. \& J. Laidley (2011). Fixity and flows in urban waterfront change, In Desfor, G. et al. (Eds.), Transforming urban waterfronts: Fixity and flows (pp. 1-13). Routledge. 
Diarra, A. (2015). La lagune Ebrié d'Abidjan à épreuve des pressions anthropopiques: Un domaine lagunaire en Côte d'Ivoire fortement agressé par les actions humaines. Bielefeld: ÉUE.

Eguavoen, I. (2021). "We do the social." Deal-making by non-accredited estate agencies, small-scale investors and tenants around low-cost rental housing in an Abidjan, Côte d'Ivoire. Afrika Focus, 34, 183213. https://doi.org/10.1163/2031356X-34020007

Eguavoen, I. (2020). Dernier refuge ou presqu'île d'opportunités? Démographie et conditions de vie à Adjahui-Coubé, un habitat spontané à Abidjan. ZEF Working Paper 187. Bonn.

Ernstson, H. \& S. Sörlin (2019). Toward comparative urban environmentalism. Situating urban natures in an emerging world of cities. In Erstson, H. \& S. Sörlin (Eds.) Grounding urban natures. Histories and futures of urban ecologies (pp. 3-53). London: The MIT Press.

Follmann, A., 2016. Governing riverscapes: Urban environmental change along the river Yamuna in Delhi, India. Stuttgart: Franz Steiner Verlag.

Gidel, M. (2011). Fragmentation on the waterfront. Coastal squatting settlements and urban renewal projects in the Caribbean. In Desfor, G. et al. (Eds.), Transforming urban waterfronts: Fixity and flows (pp. 35-54), Routledge.

Grydehøj, A. (2015). Making ground, losing space: Land reclamation and urban public space in island cities. Urban Island Studies, 1, 96-117. https://doi.org/10.20958/uis.2015.6

Hallegatte, S., C. Green, R. J. Nicholls \& J. Corfee-Morlot (2013). Future flood losses in major coastal cities. Nature Climate Change, 802-806. https://doi.org/10.1038/nclimate1979

INS (2015). Répertoire des Localités. District Autonome d’Abidjan. Abidjan: Institut National de la Statistique.

Jallow, B. P., Toure, S., Barrow, M. M. K., \& Mathieu, A. A. (1999). Coastal zone of the Gambia and the Abidjan region in Côte d'Ivoire: Sea level rise vulnerability, response strategies, and adaptation options. Climate Research, 12, 129-136. http://www.jstor.org/stable/24866007

Kabran, E. G., \& I. Eguavoen. (2019). Ferry transportation in Abidjan: Establishment, operation and sustainability of a paratransit system. ZEF Working Paper 179. Bonn.

Koffi, A., Terre, G., \& Moussa, K. (2015). Mutations et équipements dans les quartiers précaires de Zoé Bruno, Jean Folly et Sagbé à Abidjan (Côte d'Ivoire). European Scientific Journal, 11(35), 134-146.

Lawhon, M., Ernstson, H., \& Silver, J. (2013). Provincialising urban political ecology: Towards a situated UPE through African urbanism. Antipode, 46(2), 497-516. https://doi.org/10.1111/anti.12051

Pieterse, E. (2013). Grasping the unknowable. Coming to grips with African urbanism. In Pieterse, H. \& A. Simone (Eds.) Rogue urbanism. Emergent African cities (pp. 19-35). Johannesburg: Jacana Media.

Pottier, P., K. Affian, M.V. Djagoua, K.P. Anoh, Y. Krah, A. Kangah \& M. Robin (2008) La lagune Ébrié à l'épreuve de la pression anthropique. In Anoh, K.P \& P. Pottier (Eds.) Géographie du littoral de Côte d'Ivoire, éléments de réflexion pour une politique de gestion intégré (pp. 165-184), Saint-Nazaire: La Clonerie.

Rademacher, A. (2011). Reigning the river: Urban ecologies and political transformation in Kathmandu. Duke UP. https://doi.org/10.1215/9780822394525

Rocco, R. \& J. van Ballegooijen (Eds.) (2019). The Routledge handbook on informal urbanization. Routledge.

RTI info (2019). "La lagune ebrié menacée à Koumassi par un projet de remblai mémé par des opérateurs économiques”, Retrieved 5 September 2020 from https://www.youtube.com/watchv=oozKzqV_nvg

Shigata, C.B. (2017). Les systèmes fonciers coutumiers face à l'urbanisation: Recompositions sociales et conflits fonciers, Abidjan (Côte d'Ivoire). Bielefeld: ÉUE.

RLS (Rosa-Luxenburg-Stiftung) 2020. Atlas der Staatenlosen. Daten und Fakten über Ausgrenzung und Vertreibung. Berlin: RLS.

Swyngedouw, E. (2004). Social power and the urbanization of water: Flows of power. Oxford: Oxford UP.

UNEP (2015). Côte d'Ivoire. Post-conflict environmental assessment. Nairobi: United Nations Environmental Programme.

Yapi-Diahou, A. (1984). Bidonvilles d'Abidjan. Origine geo-cultuelle et profil socio-economique de 65 locataires du quartier Zoé Bruno. Abidjan: ORSTOM.

Yapi-Diahou, A. (1990). Les enfants du bidonville de Zoe Bruno à Abidjan. In UNICEF (Ed.), Bidonvilles: Urbanisation et ces incidences sur la vie de l'enfant, Abidjan (pp. 26-34). Abidjan: UNICEF.

Yapi-Diahou, A. (2000). Baraques et pouvoirs dans l'agglomération abidjanaise. Paris: L’Harmattan.

Publisher's Note Springer Nature remains neutral with regard to jurisdictional claims in published maps and institutional affiliations. 